\title{
STUDIES OF SOLID STATE ELECTROCHROMIC DEVICES BASED ON PEO/SILICEOUS HYBRIDS DOPED WITH LITHIUM
}

PERCHLORATE

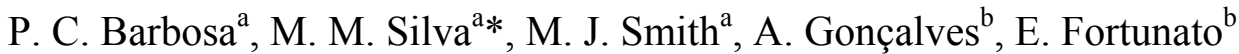 \\ ${ }^{a}$ Centro de Química, Universidade do Minho, Gualtar, 4710-057 Braga, Portugal \\ ${ }^{b}$ Centro de investigação de Materiais, Universidade Nova de Lisboa, Campus da Caparica \\ 2829 - 516 Caparica, Portugal \\ * E-mail address:nini@quimica.uminho.pt
}

\begin{abstract}
Sol-gel hybrid organic-inorganic networks, doped with a lithium salt, have been deposited on tungsten oxide $\left(\mathrm{WO}_{3}\right)$ films by spin-coating to produce a prototype smart window. The work described in this presentation is focused on the use of these networks as dual-function electrolyte/adhesive components of solid-state electrochromic devices. The performance of multi-layer electrochromic devices was characterized as a function of the precursor used to prepare the polymer electrolyte component and the guest salt concentration. The preliminary results obtained during the study of electrochromic devices are also reported. Electrochromic parameters, such as coloration efficiency, optical contrast and stability were evaluated. The prototype devices assembled exhibited stable electrochromic performance and good open-circuit memory.
\end{abstract}

Keywords: Solid polymer electrolytes; Sol-gel; Electrochromic materials; Tungsten oxide

\section{Introduction}

During the last two decades a remarkable international research effort has been dedicated to the development of solvent-free solid polymer electrolytes based on 
poly(ethylene oxide) (PEO) [1-8]. The most probable application of these materials is in primary and secondary lithium batteries [7] or electrochromic windows [9]. Thin films of electrochromic materials deposited onto transparent conductive surfaces provide the basis of variable light transmission through controlled electrochemical oxidation or reduction. Applications in windows with adjustable light transmission for use in automotive and aeronautic vehicles and houses have already been proposed [10, 11].

In recent years, the sol-gel method has been successfully used for the production of a significant number of novel organic-inorganic frameworks with tunable characteristics [1215]. The intense activity in this sub-domain of solid-state research is motivated by the technological implications that arise from the possibility of tailoring advanced multifunctional compounds by mixing organic and inorganic components at the nano-dimension level in a single material [14-17]. The synergy of this combination and the specific role of the internal organic-inorganic interfaces enhances the range of application of nanohybrid materials in areas such as electrochemistry, biology, mechanics, ceramics, electronics and optics [14, 15]. The hybrid concept seems to be particularly well-adapted to the production of advanced solidstate materials presenting ion-conducting properties, with the advantage of replacing viscous liquid systems by solid or rubbery materials [16-19].

Electrochromic materials are able to change their optical properties in a reversible manner over a large number of coloration/bleaching cycles as a result of the application of a voltage pulse. These materials are currently of interest as components of displays, rear-view mirrors, smart windows and time-elapse labels. Many polymers are soluble in common organic solvents and can be deposited as thin films, permitting the construction of low-cost devices with large display surfaces. 
In this presentation the use of sol-gel tecniques to prepare thin electrolyte films containing $\mathrm{LiClO}_{4}$ dissolved in diureasil matrices, using a spin coating technique, is described.

\section{Experimental}

\subsection{Materials}

\section{Preparation of polymer electrolytes}

The host matrix of the ormosils (organically modified silicates), prepared from poly(oxyethylene) (PEO) chains of controlled lengths (Jeffamines 2000 and 900) grafted onto siloxane groups by means of urea bridges, are classed as di-ureasils and are designated as d$\mathrm{U}(2000)$ and $d-U(900)$. In agreement with the terminology adopted in previous publications $[20,21]$, the electrolytes were identified using the notation $\mathrm{d}-\mathrm{U}(2000)_{\mathrm{n}} \mathrm{LiClO}_{4}$ and $\mathrm{d}-$ $\mathrm{U}(900)_{\mathrm{n}} \mathrm{LiClO}_{4}$. In this representation d-U(900) indicates the average molecular weight of the host di-ureasil framework and $\mathrm{n}$ expresses the salt content in terms of the number of ether oxygen atoms per $\mathrm{Li}^{+}$cation. Known amounts of lithium perchlorate were incorporated into the di-ureasil matrices, leading to the formation of ormolytes with compositions of $200 \geq n \geq$ 0.5 .

All chemical reagents are commercially available and were used without further purification. Lithium perchlorate $\left(\mathrm{LiClO}_{4}, \quad\right.$ Aldrich, $\left.99.99 \%\right)$ and $\alpha, \beta$-diamine poly(oxyethylene-co-oxypropylene) (commercially available as Jeffamine ED-2001®, Fluka, average molecular weight $2001 \mathrm{gmol}^{-1}$ ) were dried under vacuum at $25{ }^{\circ} \mathrm{C}$ for several days prior to use and $O, O^{\prime}$-bis(2-aminopropyl) polyethylene glycol (commercially designated as Jeffamine ED-900®, Fluka, average molecular weight $900 \mathrm{gmol}^{-1}$ ) were used as received. The bridging agent, 3-isocyanatepropyltriethoxysilane (ICPTES, Aldrich $95 \%$ ), was used as received. Ethanol $\left(\mathrm{CH}_{3} \mathrm{CH}_{2} \mathrm{OH}\right.$, Merck, 99.8\%) and tetrahydrofuran (THF, Merck, 99.9\%) 
were dried over molecular sieves prior to use. High purity distilled water was used in all experiments.

\section{Preparation of inorganic thin films}

Transparent conductive oxide: gallium doped zinc oxide films ( $\mathrm{ZnO}: \mathrm{Ga})$ were deposited on glass substrates by r.f. (13.56 MHz) magnetron sputtering using a ceramic oxide target $\left(\mathrm{ZnO}: \mathrm{Ga}_{2} \mathrm{O}_{3}(95: 5 \mathrm{wt} \%)\right) ; 5 \mathrm{~cm}$ diameter, supplied by SCM, Suffern, NY, USA). The sputtering process was carried out at room temperature, with an argon flow of $20 \mathrm{sccm}$ and a deposition pressure of $0.11 \mathrm{~Pa}$. The distance between the substrate and the target was $10 \mathrm{~cm}$ and the rf power was maintained constant at $175 \mathrm{~W}$. Further details of film preparation as well as physical properties of the product can be found in ref [22].

Electrochromic films: tungsten oxide films $\left(\mathrm{WO}_{3}\right)$ were prepared by thermal evaporation using $\mathrm{WO}_{3}$ pellets (SCM, 99.99\% purity). The deposition pressure was $1.2 \times 10^{-3} \mathrm{~Pa}$ with a deposition rate of $1.03 \mathrm{~nm} / \mathrm{seg}$.

\subsection{Synthesis}

The synthesis of $\mathrm{LiClO}_{4}$-doped di-ureasils has been described in detail elsewhere [20, 21]. The procedure used for $\mathrm{d}-\mathrm{U}(900)_{\mathrm{n}} \mathrm{LiClO}_{4}$ involved grafting a diamine containing approximately 15.5 oxyethylene repeat units onto the ICPTES precursor, to yield the di-urea cross-linked hybrid precursor. This material was subsequently hydrolyzed and condensed in the sol-gel stage of the synthesis to induce the growth of the siloxane framework.

Step 1 - Synthesis of the di-ureasil precursor, d-UPTES(900): $2.0 \mathrm{~g}$ of Jeffamine ED$900 ®$ was dissolved in $10 \mathrm{ml}$ of THF with stirring. A volume of $1.097 \mathrm{~mL}$ of ICPTES was added to this solution in a fume cupboard (molar proportion 1 Jeffamine ED-900®: 2 ICPTES). The flask was then sealed and the solution stirred for about $12 \mathrm{~h}$ at moderate temperature $\left(\approx 40{ }^{\circ} \mathrm{C}\right)$. A urea cross-linked organic-inorganic material, designated as di- 
ureapropyltriethoxysilane (d-UPTES(900)), was obtained under these conditions. The grafting process was followed by infrared monitoring.

Step 2 - Synthesis of the di-ureasil xerogels, $d-U(900)_{n} \mathrm{LiClO}_{4}$ : A volume of $1.038 \mathrm{~mL}$ of $\mathrm{CH}_{3} \mathrm{CH}_{2} \mathrm{OH}$, an appropriate mass of $\mathrm{LiClO}_{4}$ and $0.120 \mathrm{~mL}$ of water were added to the dUPTES(900) solution prepared in the previous step (molar proportion 1 ICPTES: 4 $\mathrm{CH}_{3} \mathrm{CH}_{2} \mathrm{OH}: 1.5 \mathrm{H}_{2} \mathrm{O}$ ). The mixture was stirred, at room temperature, in a sealed flask for approximately $30 \mathrm{~min}$ and then decanted into a Teflon ${ }^{\circledR}$ mould, covered with perforated membrane of Parafilm ${ }^{\circledR}$ and stored in a fume cupboard for $24 \mathrm{~h}$. The mould was transferred to an oven at $50{ }^{\circ} \mathrm{C}$ and the sample was aged for a period of 3 weeks. A final period of 1 week at $80{ }^{\circ} \mathrm{C}$ completed the process.

The xerogels with $\mathrm{n}$ greater than 5 were obtained as flexible transparent, monolithic films with a yellowish hue, whereas the compounds with $n=1$ and 0.5 were rather brittle, powdery agglomerates.

\subsection{Experimental techniques}

Ionic conductivity. The total ionic conductivity of the ormolyte was determined by locating an electrolyte disk between two $10 \mathrm{~mm}$ diameter ion-blocking gold electrodes (Goodfellow, $>99.95 \%$ ) to form a symmetrical cell. The electrode/electrolyte/electrode assembly was secured in a suitable constant-volume support [23] and installed in a Buchi TO51 tube oven. A calibrated type K thermocouple positioned close to the electrolyte film was used to measure the sample temperature with a precision of about $\pm 0.2^{\circ} \mathrm{C}$. Impedance measurements were carried out at frequencies between $96 \mathrm{kHz}$ and $500 \mathrm{mHz}$ with a Solartron $1250 \mathrm{FRA}$ and $1286 \mathrm{ECI}$, over a temperature range of 20 to $90^{\circ} \mathrm{C}$. Measurements of conductivity were effected during heating cycles. The reproducibility of recorded conductivities was confirmed by comparing the results obtained for different electrolyte 
samples removed from the same film and subjected to precisely-reproduced assembly and characterization procedures. Repeated measurements on samples confirmed that reproducibility was better than $5 \%$. The experimental procedure adopted confirmed the correct operation of the cell support used to effect measurements and the mechanical stability of the sample films. A typical impedance spectra is illustrated in Figure 1.

Thermal analysis. Electrolyte sections were removed from dry films and transferred to $40 \mu \mathrm{L}$ aluminium cans with perforated lids within a dry argon-filled glovebox. These samples were subjected to thermal analysis under a flowing argon atmosphere between 25 and $300^{\circ} \mathrm{C}$ and at a heating rate of $5^{\circ} \mathrm{C} \cdot \mathrm{min}^{-1}$ using a Mettler DSC 821e. Samples for thermogravimetric studies were prepared in a similar manner, transferred to open crucibles and analyzed using a Rheometric Scientific TG1000 thermobalance operating under a flowing argon atmosphere. A heating rate of $10^{\circ} \mathrm{C} \cdot \mathrm{min}^{-1}$ was used with all samples.

Electrochemical stability. Evaluation of the electrochemical stability window of electrolyte compositions was carried out within a dry argon-filled glovebox using a twoelectrode cell configuration. Preparation of a $25 \mu \mathrm{m}$ diameter gold microelectrode surface by the conventional polishing routine was completed outside the dry-box prior to washing and drying before transfer into the dry-box. The cell assembly was initiated by locating a clean lithium disk counter electrode (Aldrich, 99.9\%, 10mm diameter, $1 \mathrm{~mm}$ thick) on a stainless steel current collector. A thin-film sample of electrolyte was centered over the counter electrode and the cell assembly was completed by locating and supporting the microelectrode in the centre of the electrolyte disk. The assembly was held together firmly with a clamp and electrical contacts were made to the Autolab PGSTAT-12 (Eco Chemie) used to record voltammograms at a scan rate of $100 \mathrm{mVs}^{-1}$. Measurements were conducted at room temperature within a Faraday cage located inside the measurement glovebox. 
Device fabrication and characterization. Device assembly was carried out by direct application of a small volume of the gel electrolyte to the surface of a glass plate onto which a $\mathrm{ZnO}: \mathrm{Ga} / \mathrm{WO}_{3}$ coating had been previously deposited. Two layers of gel were spread onto 2.5 x $2.5 \mathrm{~cm}$ substrates by using a spinner, with a rotation rate of $2000 \mathrm{rpm}$ for $40 \mathrm{~s}$. The thicknesses used for each layer were $\mathrm{ZnO}: \mathrm{Ga}-200 \mathrm{~nm}$ and $\mathrm{WO}_{3}-300 \mathrm{~nm}$. A second glass plate with $\mathrm{ZnO}: \mathrm{Ga}$ coating was placed on top of the gel electrolyte sample. The optical transmission measurements were obtained using a Shimadzu-3100 UV-Vis-NIR double beam spectrophotometer in the wavelength range from 300 to $900 \mathrm{~nm}$. The coloring and bleaching voltages were 0 and $4.0 \mathrm{~V}$, respectively, for all the devices under analysis.

\section{Results and Discussion}

\section{1 - Electrochemical behaviour of the $d-U(900)_{n} \mathrm{LiClO}_{4}$ ormolytes}

\section{Conductivity Measurements}

The ionic conductivity of the polymer electrolytes was measured as a function of salt composition and temperature. The objective of this characterization was to identify the electrolyte with the most favorable behaviour for use as a component of the electrochromic display. In general, salts with a polarizing cation and a large anion with a well-delocalized charge, and therefore also with a low lattice energy, are the most suitable for use in polymer electrolytes [7]. In spite of the dangers associated with the anion, $\mathrm{LiClO}_{4}$ is a salt that satisfies the conditions mentioned above and provides good electrolyte behaviour, relative to the d$\mathrm{U}(900)$ di-ureasils doped with lithium triflate, $\mathrm{LiCF}_{3} \mathrm{SO}_{3}$ [24]. Figures 2a) and b) ilustrate the variation of total ionic conductivity of the d-U(900) $)_{\mathrm{n}} \mathrm{LiClO}_{4}$ electrolyte as a function of temperature. These figures also demonstrate the non-linear variation of ionic conductivity with temperature in the range between 25 and $100{ }^{\circ} \mathrm{C}$. In addition, the plots reveal that there is a conductivity maximum at $15 \geq \mathrm{n} \geq 8$ at temperatures above $30^{\circ} \mathrm{C}$, an observation confirmed 
by the conductivity isotherms shown in Figure 3. For compositions with high salt content $(\mathrm{n}<$ 8) the total ionic conductivity decreases, particularly at lower temperatures.

Figure 4 is included to demonstrate the effect of the choice of ureasils networks on the total ionic conductivity. The Arrenhius plots show the variation of ionic conductivity with temperature of selected compositions of the $U(2000), U(900)$ and $U(600)$ d-ureasils [25]. As expected, U(600)-based ormolytes are less conducting than the other d-ureasils, because the PEO chain segments of $U(600)$ are very short, restricting the chain mobility necessary to transport the guest ions. The higher molecular weight PEO chains of the doped U(900) and $\mathrm{U}(2000)$ di-ureasils were found to support higher conductivity [26, 27].

\section{Thermal analysis}

From the DSC analysis of the d-U(900) ${ }_{\mathrm{n}} \mathrm{LiClO}_{4}$ di-ureasils it was possible to conclude that these materials are completely amorphous over the range of temperatures studied. The onset of thermal decomposition was estimated from thermogravimetric analysis. The upper limit of the application of di-ureasils incorporating $\mathrm{LiClO}_{4}$ is effectively determined by the guest salt concentration. The results presented in Figure 5 show a decrease in thermal stability with increasing salt concentration, confirming that the salt has a destabilizing influence on the hybrid matrix host. The highest decomposition temperature of $283^{\circ} \mathrm{C}$ was registered for the $\mathrm{n}$ $=200$ composition, a value similar to that observed for the $\mathrm{d}-\mathrm{U}(2000)_{\mathrm{n}} \mathrm{LiClO}_{4}$ di-ureasil [25]. The difference in behaviour of d-ureasils $\mathrm{U}(2000)$ and $\mathrm{U}(900)$ doped with $\mathrm{LiClO}_{4}$ is also clear in Figure 5, where for $\mathrm{n}<25$ compositions, the d-U(900) ${ }_{\mathrm{n}} \mathrm{LiClO}_{4}$ di-ureasils show a much lower thermal stability $\left(209^{\circ} \mathrm{C}\right)$ than the corresponding d-U(2000) ${ }_{\mathrm{n}} \mathrm{LiClO}_{4}$ electrolyte [25]. In spite of this moderate thermal stability, these materials are appropriate for use in a variety of technological applications at ambient or close-to-ambient temperatures. 
The ionic mobility of charged species in a polymer electrolyte is to a large extent determined by the mobility of the polymer host segments [7]. As expected from previous studies of similar PEO/siloxane ormolytes [25, 28], an increase in salt concentration causes a corresponding increase in $\mathrm{Tg}$ of the $\mathrm{d}-\mathrm{U}(900)_{\mathrm{n}} \mathrm{LiClO}_{4}$ di-ureasils (Figure 6). The poor mechanical properties of the compositions with the highest salt content $(n=0.5$ and $n=1)$ limit the practical usefulness of the electrolyte in the sense that the electrolyte performs inadequately as a device component. It is interesting to observe that the Tg of electrolytes based on the di-ureasil matrix is almost constant $\left(-50^{\circ} \mathrm{C}\right)$ in samples with $\mathrm{n} \geq 40$. This observation suggests that the PEO chains of the d-U(900) ${ }_{n} \mathrm{LiClO}_{4}$ are not involved in the coordination of the lithium ions in this range of composition. Figure 6 also shows that for compositions with $\mathrm{n} \leq 40$ the addition of guest ionic species does not affect the d-U(2000) matrix host so significantly as in the case of the $\mathrm{d}-\mathrm{U}(900)_{\mathrm{n}} \mathrm{LiClO}_{4}$ compositions.

\section{Electrochemical stability}

The electrochemical stability range of the lithium-doped di-ureasils was determinated by microelectrode cyclic voltammetry over the potential range between $-0.5 \mathrm{~V}$ and $4.5 \mathrm{~V}$. The potential limit for the electrolyte system corresponds to the value at which a rapid rise in current was observed and where the current continued to increase as the potential was swept in the same direction. The overall stability of electrolytes was excellent, with no electrochemical oxidation occurring at anodic potentials less than about $5 \mathrm{~V}$ versus $\mathrm{Li} / \mathrm{Li}^{+}$. Figure 7 shows a typical voltammogram of an electrolyte samples of d-U(900) ${ }_{8} \mathrm{LiClO}_{4}$ composition. 


\section{2 - Electrochromic device operation}

The scheme in Figure 8 shows the structure of the prototype electrochemical display device characterized in the preliminary experiments reported herein. The optical behaviour of the display was reproducible and superior to that observed with comparable devices employing conventional liquid electrolytes, particularly with respect to the stability of the electrochromic material. We observed that the initial value of the luminous transmittance for the case of use of polymer electrolytes was also slightly higher than that of comparable devices with liquid $\mathrm{LiClO}_{4}$ electrolyte. This may be due to the significant reduction of the electrolyte layer thickness made possible through the use of the polymeric component. Leakage performance, memory effect and humidity deterioration were also notably improved. The results presented in Figures 9 and 10 report the optical transmittance in the wavelength range 300-900 $\mathrm{nm}$ for the devices based on $\mathrm{d}-\mathrm{U}(2000)_{\mathrm{n}} \mathrm{LiClO}_{4}$ and $\mathrm{d}-\mathrm{U}(900)_{\mathrm{n}} \mathrm{LiClO}_{4}$ diureasils, respectively. It is clear that the best results are obtained for compositions with high ionic conductivity. In the case of the $\mathrm{d}-\mathrm{U}(2000)_{\mathrm{n}} \mathrm{LiClO}_{4}$ and $\mathrm{d}-\mathrm{U}(900)_{\mathrm{n}} \mathrm{LiClO}_{4}$ di-ureasils the ormolyte compositions are $20<\mathrm{n}<40$ and $8<\mathrm{n}<15$, respectively. While these exploratory results are encouraging it is obviously necessary to optimize device assembly procedures and further improve mechanical and conductivity performance of the electrolyte layer to demonstrate the full potential of sol-gel derived solid polymer electrolytes as multifunctional components.

Table 1 summarizes the average transmittance and optical density exhibited by devices. The average transmittance in the visible region of the spectrum was above of $68 \%$ for all the samples analyzed. After coloration the devices assembled with d-U(2000) ${ }_{20} \mathrm{LiClO}_{4}$ and d-U(900) ${ }_{8} \mathrm{LiClO}_{4}$ di-ureasils present an average transmittance of $44 \%$ and an optical density 
of 0.30. All the devices under analysis presented good stability, and may be of interest for application in smart windows (Figure 11).

\section{Conclusions}

In this work novel di-ureasil (d-U(900) and d-U(2000)) composites incorporating $\mathrm{LiClO}_{4}$ guest salt were investigated and used as dual-function components in prototype devices. These electrolytes were obtained as amorphous films, with excellent mechanical adaptation and adhesion to the electrode surface and good electrochemical and thermal stability. These materials provide significant advantages in optical performance, cycle lifetime and durability of the electrochromic device relative to conventional liquid electrolytes. In general, the use of solid polymer electrolytes may be expected to improve leakage performance, memory effect and humidity resistance. In addition, the sol-gel processing strategy provides ready access to materials with a greater precision of structural control than that of traditional methods of polymer synthesis. Appropriate alterations in the sol-gel procedure may permit progressive improvements in the mechanical and conductivity behaviour of the electrolyte component. The encouraging initial results obtained with electrochromic smart windows based on di-ureasil matrices doped with $\mathrm{LiClO}_{4}$, provide motivation for future optimization studies.

\section{Acknowledgments}

The authors are pleased to acknowledge the support provided by University of Minho and the Fundação para a Ciência e Tecnologia (contracts POCI/QUI/59856/2004, POCTI/CTM/48853/2002, POCTI/3/686, SFRH/BD/22707/2005) for laboratory facilities. M. M. Silva gratefully acknowledges the Fundação Oriente for travel funds. 


\section{References}

[1] B.E. Fenton, J.M. Parker, P.V. Wright, Polym.14 (1973) 589.

[2] P.V. Wright, Br. Polym. J. 7 (1975) 319.

[3] M.B. Armand, J.M. Chabagno, M.J. Duclot, in: Proceedings of the $2^{\text {nd }}$ International Meeting on Solid Electrolytes, St. Andrews, 1978 (Extended abstract 6.5.1).

[4] C.A. Vincent, Prog. Solid. St. Chem., 17 (1987) 145.

[5] M. Armand, Faraday Discuss. Chem. Soc. 88 (1989) 65.

[6] B. Scrosati, Proceedings of the $2^{\text {nd }}$ International Symposium on Polymer Electrolytes, Elsevier Applied Science, Amsterdam, 1990.

[7] a) F.M. Gray, Solid Polymer Electrolytes: Fundamentals and Technological Applications, VCH Publishers, Inc, New York, 1991; b) F.M. Gray, Polymer Electrolytes, RSC Materials Monographs, Royal Society of Chemistry, London, 1997; c) M.B. Armand, in: J.R. MacCallum and C.A. Vincent (Eds.), Polymer Electrolyte Reviews, Vol 1, Elsevier, London 1987.

[8] Proc. $6^{\text {th }}$ International Symposium on Polymer Electrolytes, Kanagawa, Japan, 1-6 Nov., 1998; Electrochim. Acta 45 (2000).

[9] B. Scrosati, Applications of Electroactive Polymers, Chapman and Hall, London, 1994.

[10] T. Kase, M. Kawai, M. Ura, SAE Technical Paper Series, 861362 (1986).

[11] C.M. Lampert, Materials Today 7 (2004) 28.

[12] C.J. Brinker, G.W. Scherer, Sol-Gel Science: The Physics and Chemistry of Sol-Gel Processing, Academic Press, London, 1990.

[13] P. Gomez-Romero, C. Sanchez, Functional Hybrid Materials, Wiley Interscience, New York, 2003.

[14] P. Judeinstein, C. Sanchez, J. Mater. Chem. 6 (1996) 511.

[15] C. Sanchez, F. Ribot, B. Lebeau, J. Mater. Chem. 9 (1999) 35. 
[16] V. de Zea Bermudez, C. Poinsignon, M. Armand, J. Mater. Chem. 7 (1997) 1677.

[17] P. Judeinstein, J.Livage, A. Zarudiansky, R. Rose, Solid State Ionics 28 (1988) 1722.

[18] M. Armand, Adv. Mater. 2 (1990) 278.

[19] B. Orel, U.O. Krasovec, U.L. Stangar, J. Sol-Gel Sci. Technol. 11 (1998) 87.

[20] L.D. Carlos, V. de Zea Bermudez, M.C. Duarte, M.M. Silva, C.J. Silva, M.J. Smith, M. Assunção, L. Alcácer, in: C. Ronda, T. Welker (Eds.), Physics and Chemistry of Luminescent Materials VI, Vol. 97-29, Electrochemical Soc. Proc., San Francisco, 1998, p. 352.

[21] V. de Zea Bermudez, L.D. Carlos, M.C. Duarte, M.M. Silva, C.J. Silva, M.J. Smith, M. Assunção, L. Alcácer, J. Alloys Compounds 21 (1998) 275.

[22] V. Assunção, E. Fortunato, A. Marques, A. Gonçalves, I. Ferreira, H. Águas, R. Martins, Thin Solid Films 442 (2003) 102.

[23] C.J.R. Silva, M. J. Smith, Electrochim. Acta 40 (1995) 2389.

[24] M.M. Silva, V. de Zea Bermudez, L.D. Carlos, M.J. Smith, Electrochim. Acta 45 (2000) 1467.

[25] M.M. Silva, S.C. Nunes, P.C. Barbosa, A. Evans, V. de Zea Bermudez, M.J. Smith’ D. Ostrovskii, Electrochimica Acta, in press.

[26] C. Berthier, W. Gorecki, M. Minier, M.B. Armand, J.M. Chabagno, P. Rigaud, Solid State Ionics 11 (1983) 91.

[27] S.M. Gomes Correia, V. de Zea Bermudez, M.M. Silva, S. Barros, R.A. Sá Ferreira, L.D. Carlos, A.P. Passos de Almeida, M.J. Smith, Electrochimica Acta 47 (2002) 2421.

[28] S.C. Nunes, V. de Zea Bermudez, M.M. Silva, S. Barros, M.J. Smith, E. Morales, L.D. Carlos, J. Rocha, Solid State Ionics 176 (2005) 1591. 

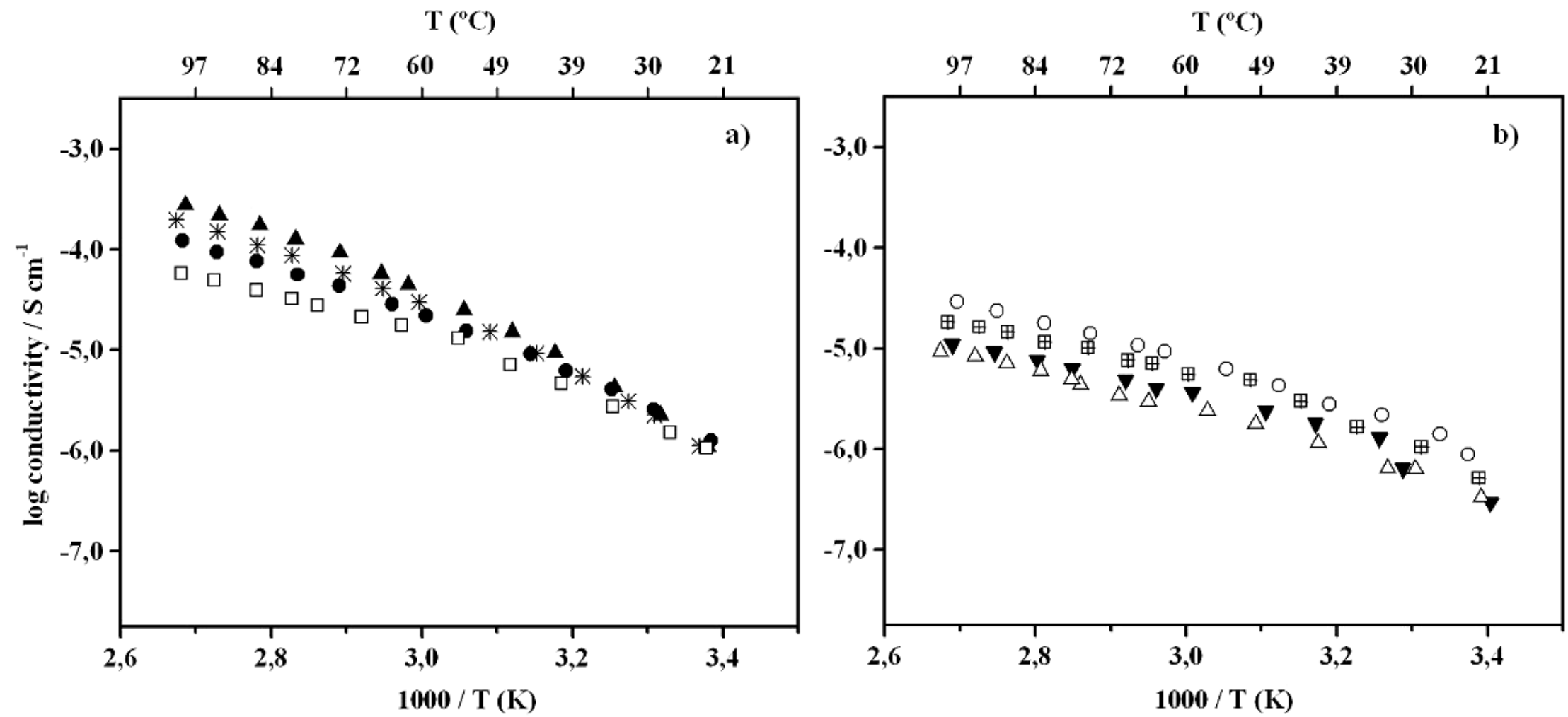

Fig. 2(a) and (b). Variation of conductivity of selected d-U(900) ${ }_{n} \mathrm{LiClO}_{4}$ di-ureasils with temperature $(\mathrm{n}=8 \boldsymbol{\Delta}, 10 *, 15 \boldsymbol{\bullet}, 25 \square, 35 \mathrm{O}, 60$ 田,

$80 \nabla$ and $100 \triangle$ ). 


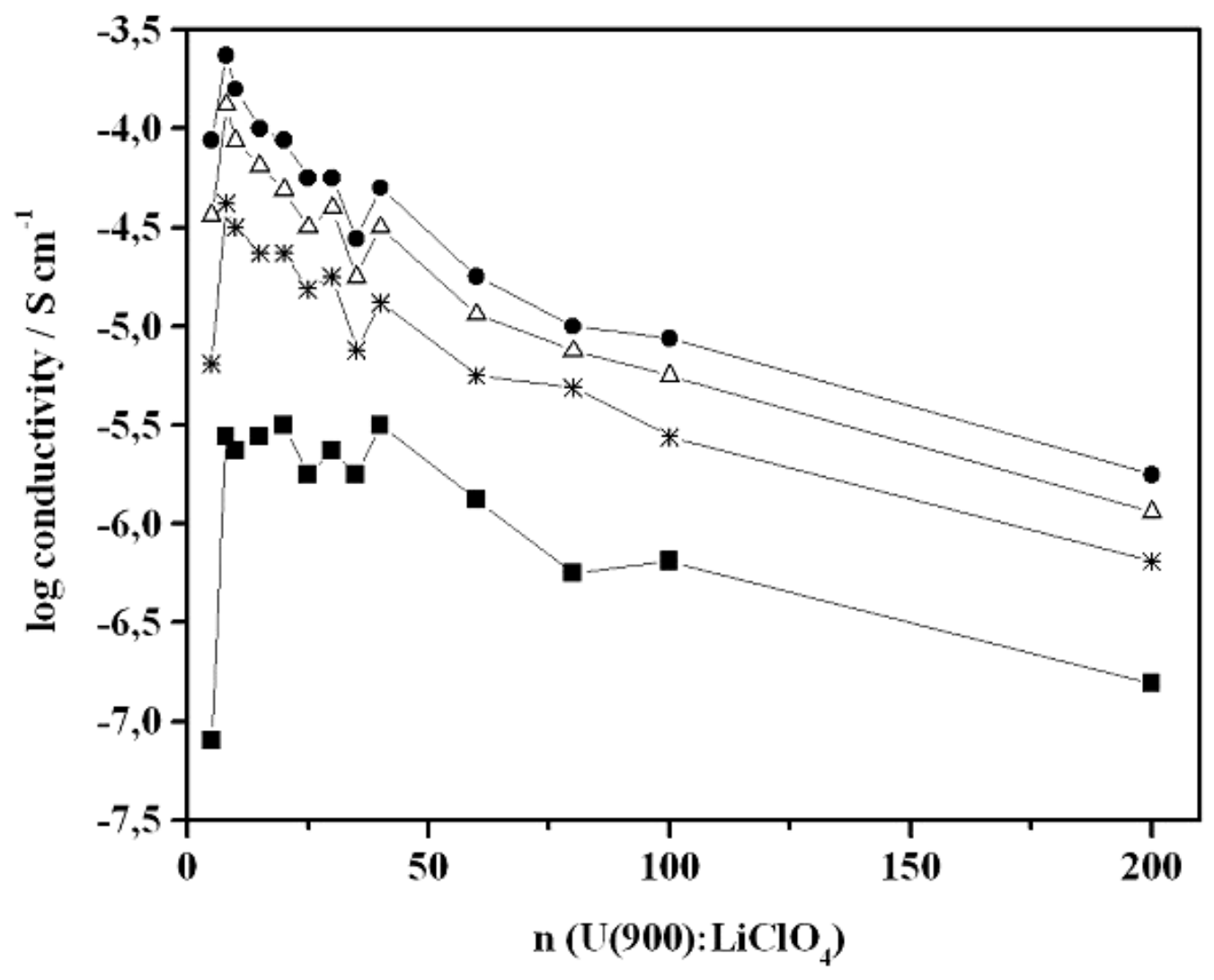

Fig. 3. Isothermal variation of ionic conductivity of d-U(900) $)_{n} \mathrm{LiClO}_{4}$ di-ureasils $\left(30^{\circ} \mathrm{C} \boldsymbol{\square}, 60^{\circ} \mathrm{C} *, 80^{\circ} \mathrm{C} \triangle\right.$ and $95^{\circ} \mathrm{C}$ 


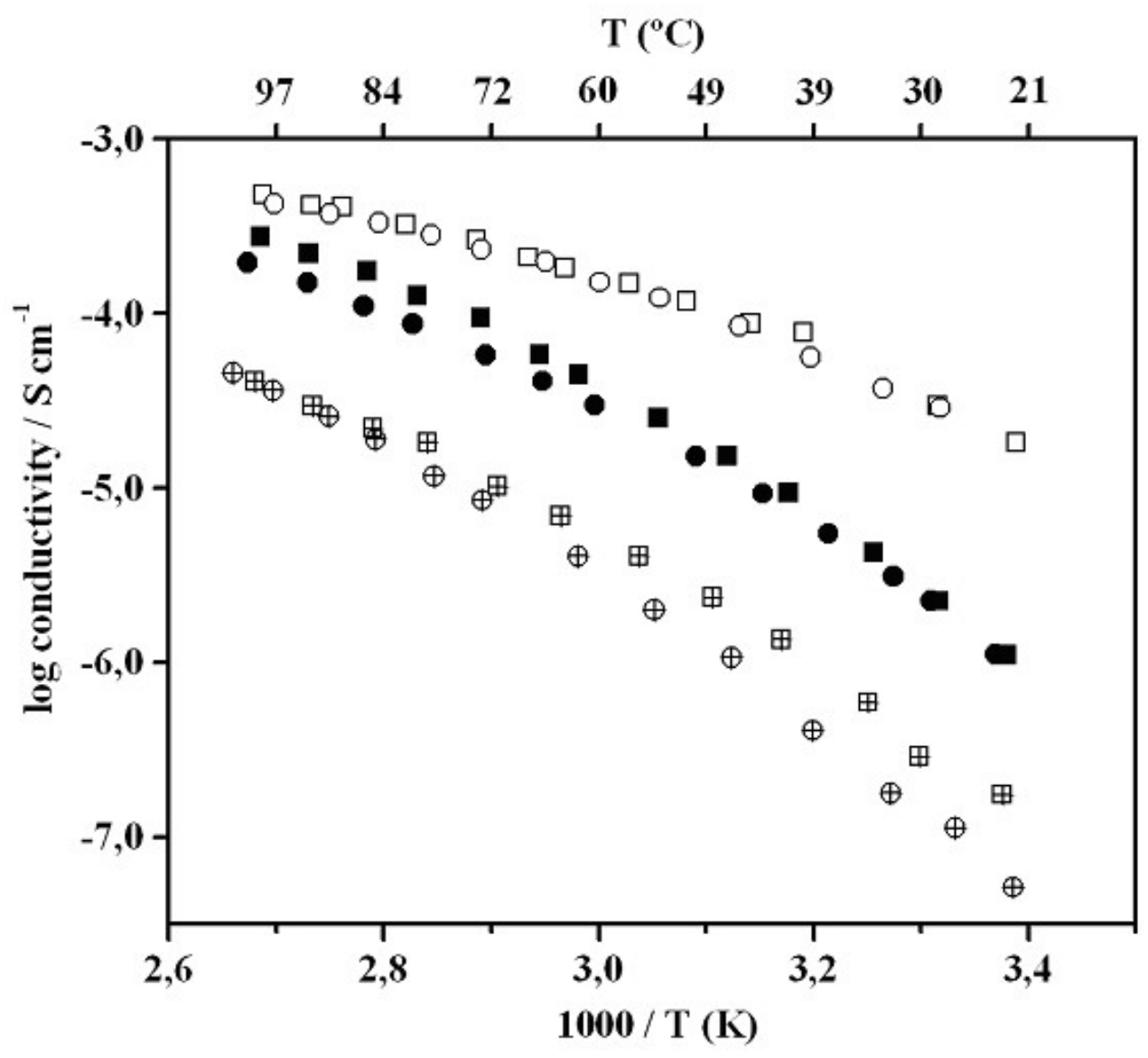

Fig. 4. Comparison of ionic conductivity between d-U(2000) ${ }_{n} \mathrm{LiClO}_{4}, \mathrm{~d}-\mathrm{U}(900)_{\mathrm{n}} \mathrm{LiClO}_{4}$ and d$\mathrm{U}(600)_{\mathrm{n}} \mathrm{LiClO}_{4}$ di-ureasils $\left(\mathrm{U}(2000)_{20} \mathrm{LiClO}_{4} \square, \mathrm{U}(2000)_{30} \mathrm{LiClO}_{4} \quad \mathrm{O}, \mathrm{U}(900)_{8} \mathrm{LiClO}_{4}\right.$ $\left.\left.\mathrm{U}(900)_{10} \mathrm{LiClO}_{4} \odot, \mathrm{U}(600)_{10} \mathrm{LiClO}_{4} \boxplus, \mathrm{U}(600)_{5} \mathrm{LiClO}_{4} \oplus\right)\right)$ 


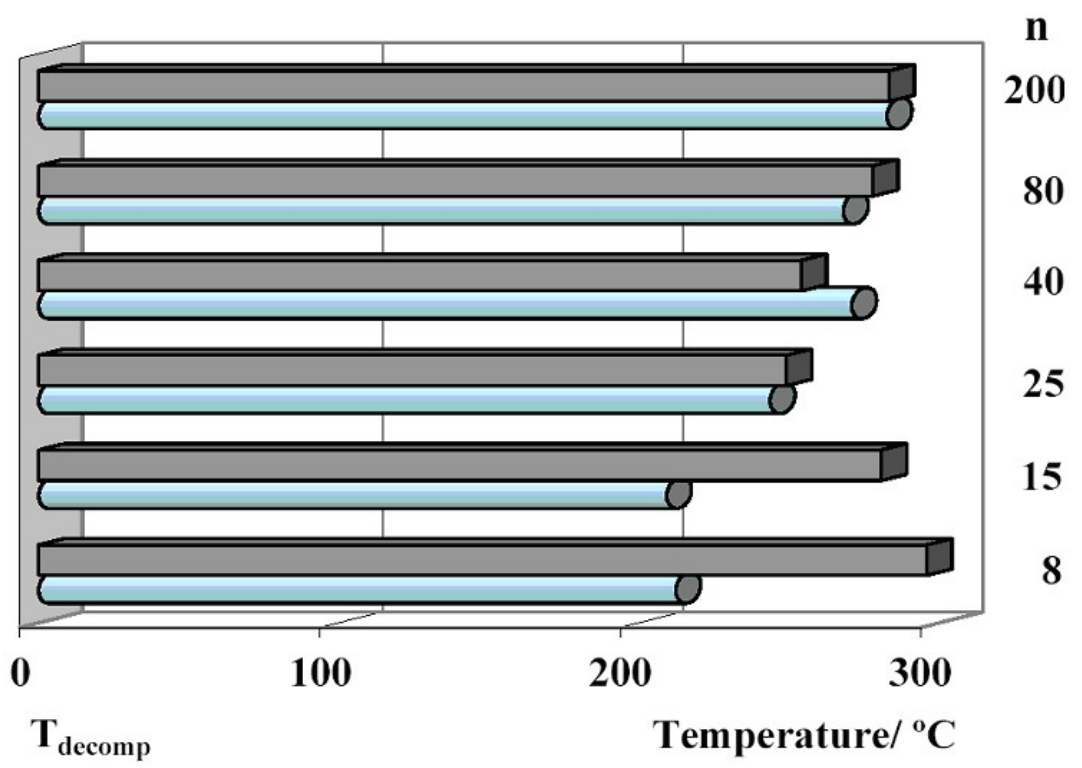

Fig. 5. Extrapolated onset of degradation temperatures from TGA results: oval rods $-\mathrm{d}-\mathrm{U}(900)_{\mathrm{n}} \mathrm{LiClO}_{4}$, rectangular rods $-\mathrm{d}-\mathrm{U}(2000)_{\mathrm{n}} \mathrm{LiClO}{ }_{4}$. 


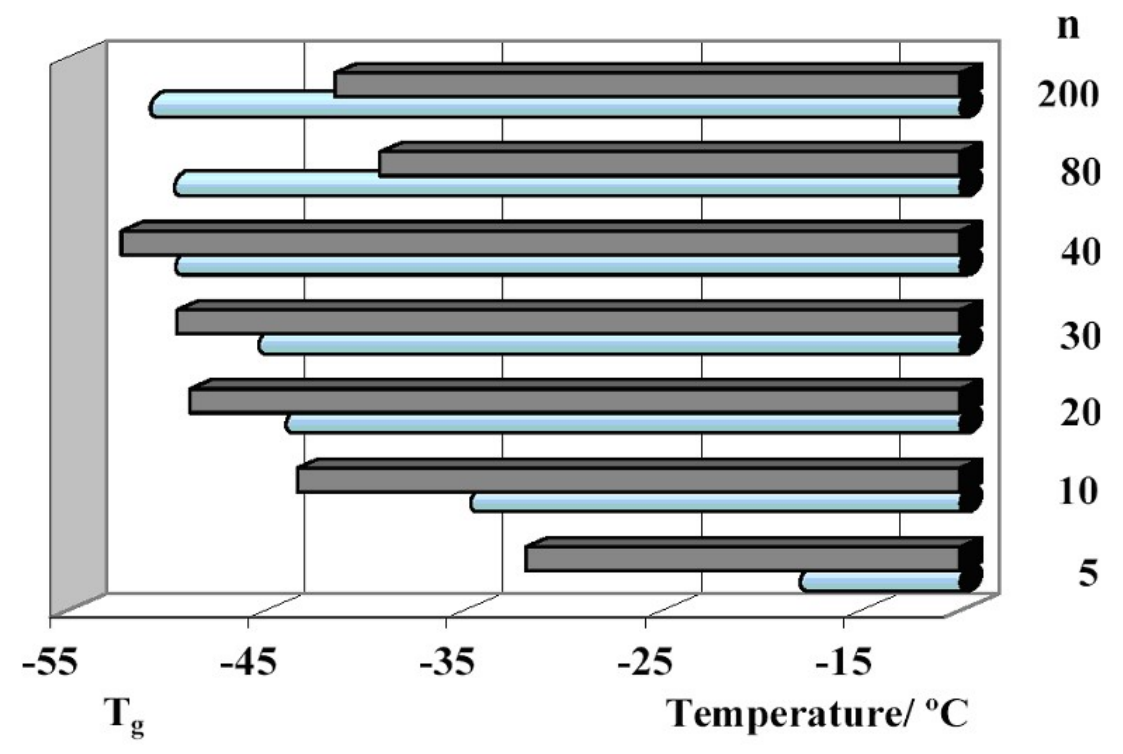

Fig. 6. Extrapolated onset of glass transition temperatures of di-ureasils: oval rods $-\mathrm{d}-$ $\mathrm{U}(900)_{\mathrm{n}} \mathrm{LiClO}_{4}$, rectangular rods $-\mathrm{d}-\mathrm{U}(2000)_{\mathrm{n}} \mathrm{LiClO}_{4}$. 


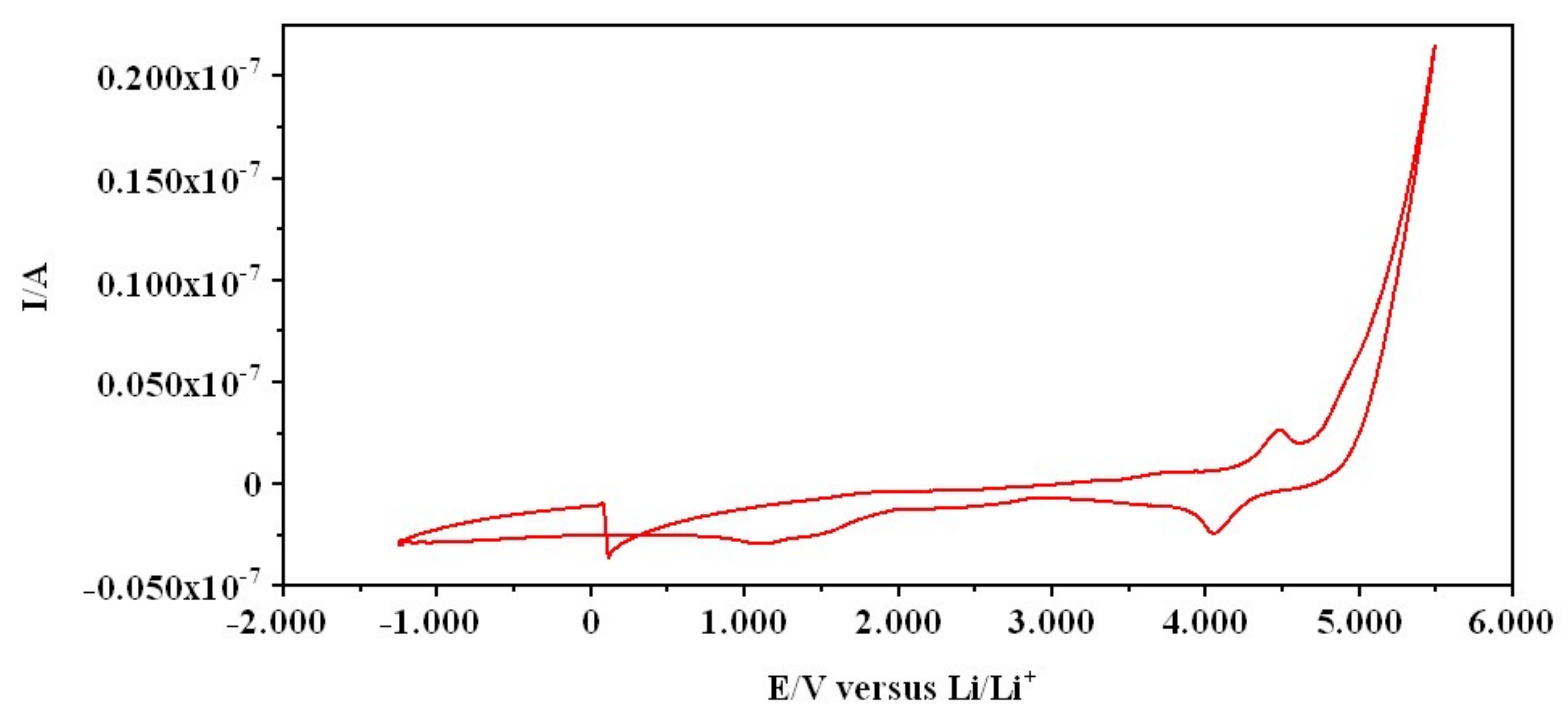

Fig. 7. Voltammogram of $\mathrm{d}-\mathrm{U}(900)_{8} \mathrm{LiClO}_{4}$ electrolyte at a $25 \mu \mathrm{m}$ diameter gold microelectrode vs $\mathrm{Li} / \mathrm{Li}+$. Initial sweep direction is anodic and sweep rate is $100 \mathrm{mVs}^{-1}$. 


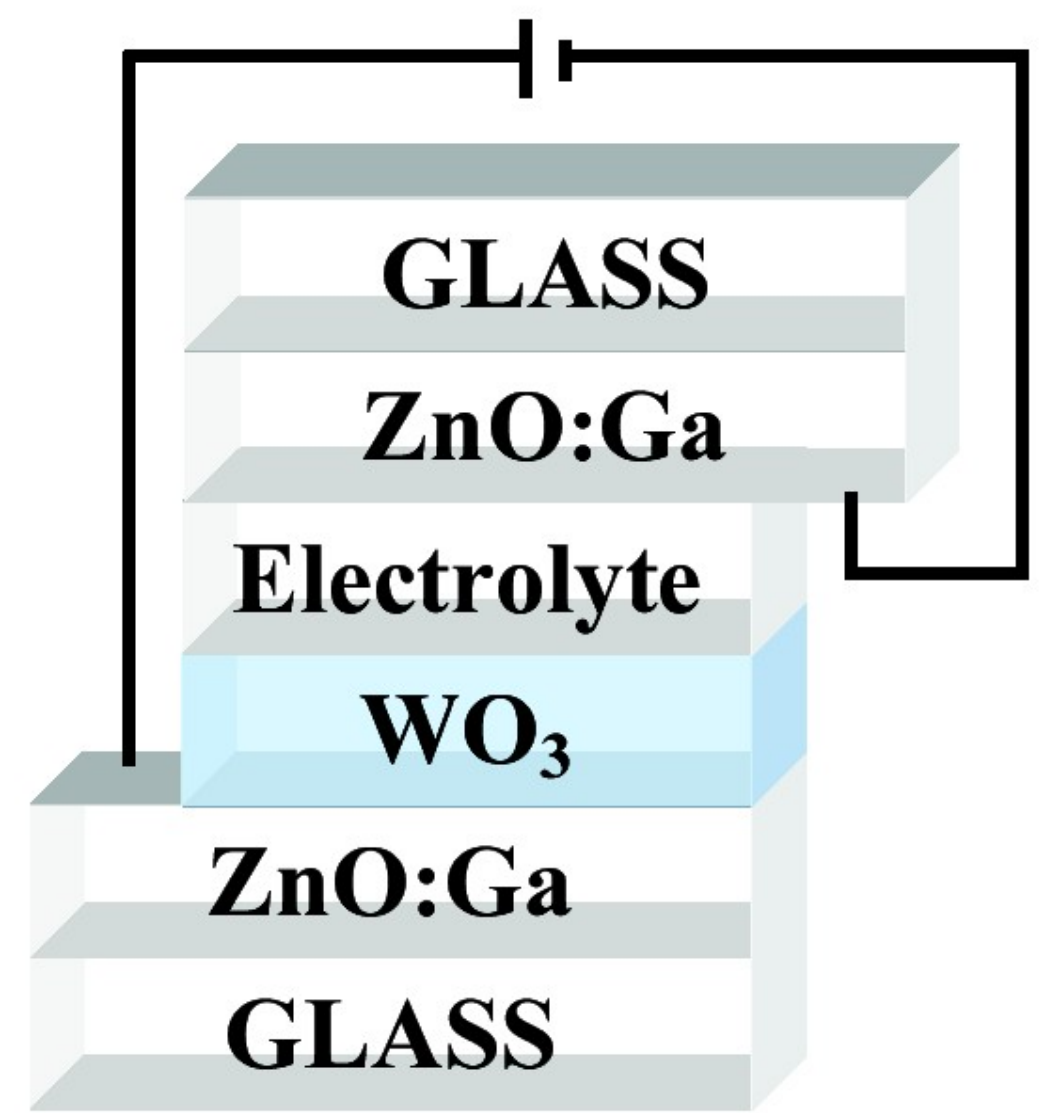

Fig. 8. Schematic illustration of the prototype electrochromic device structure. 

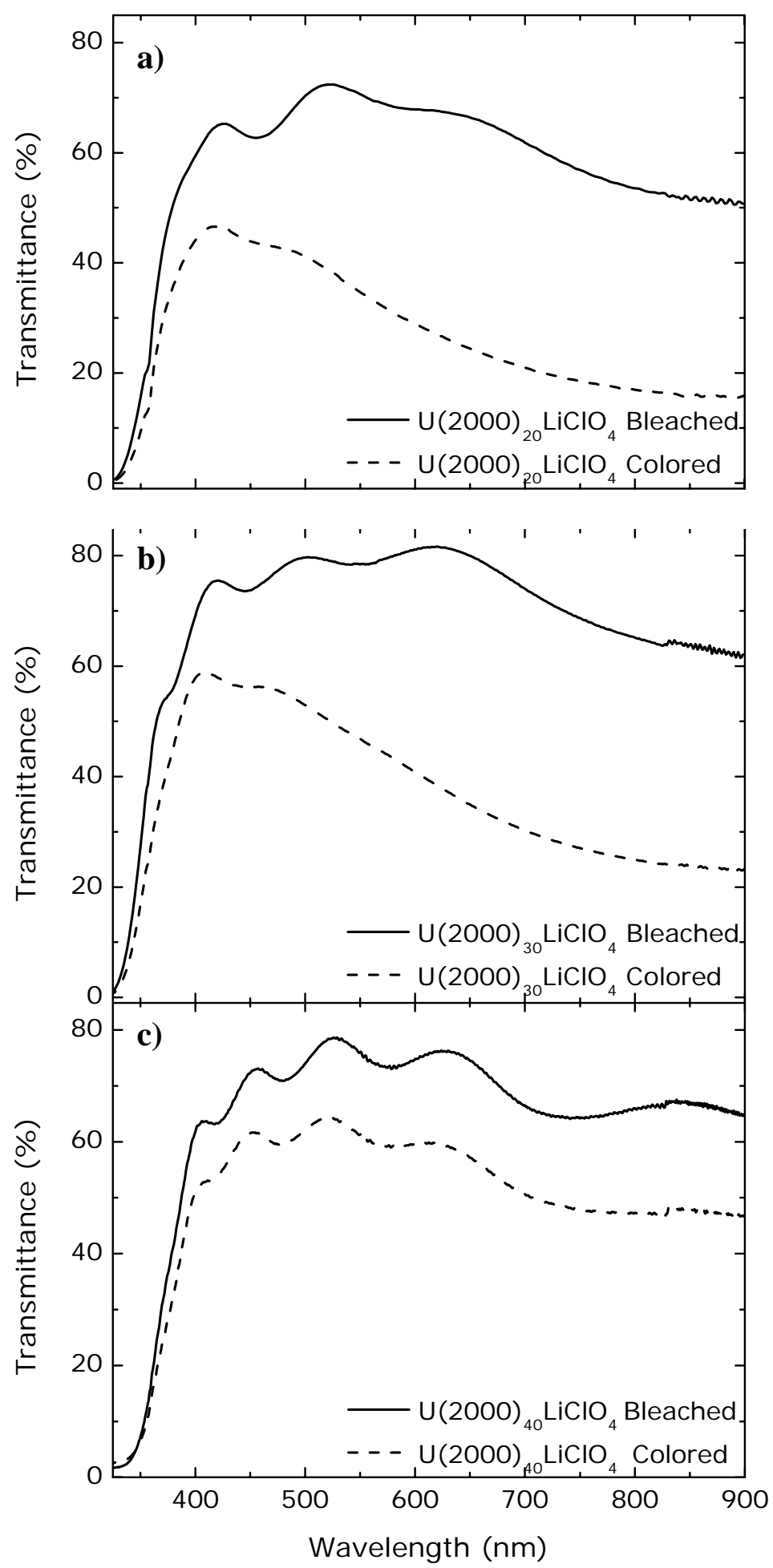

Fig. 9. Optical transmittance as a function of wavelength for the electrochromic device in bleached and colored state using (a) d-U(2000) ${ }_{20} \mathrm{LiClO}_{4}$; (b) d-U(2000) ${ }_{30} \mathrm{LiClO}_{4}$; (c) d$\mathrm{U}(2000)_{40} \mathrm{LiClO}_{4}$. 


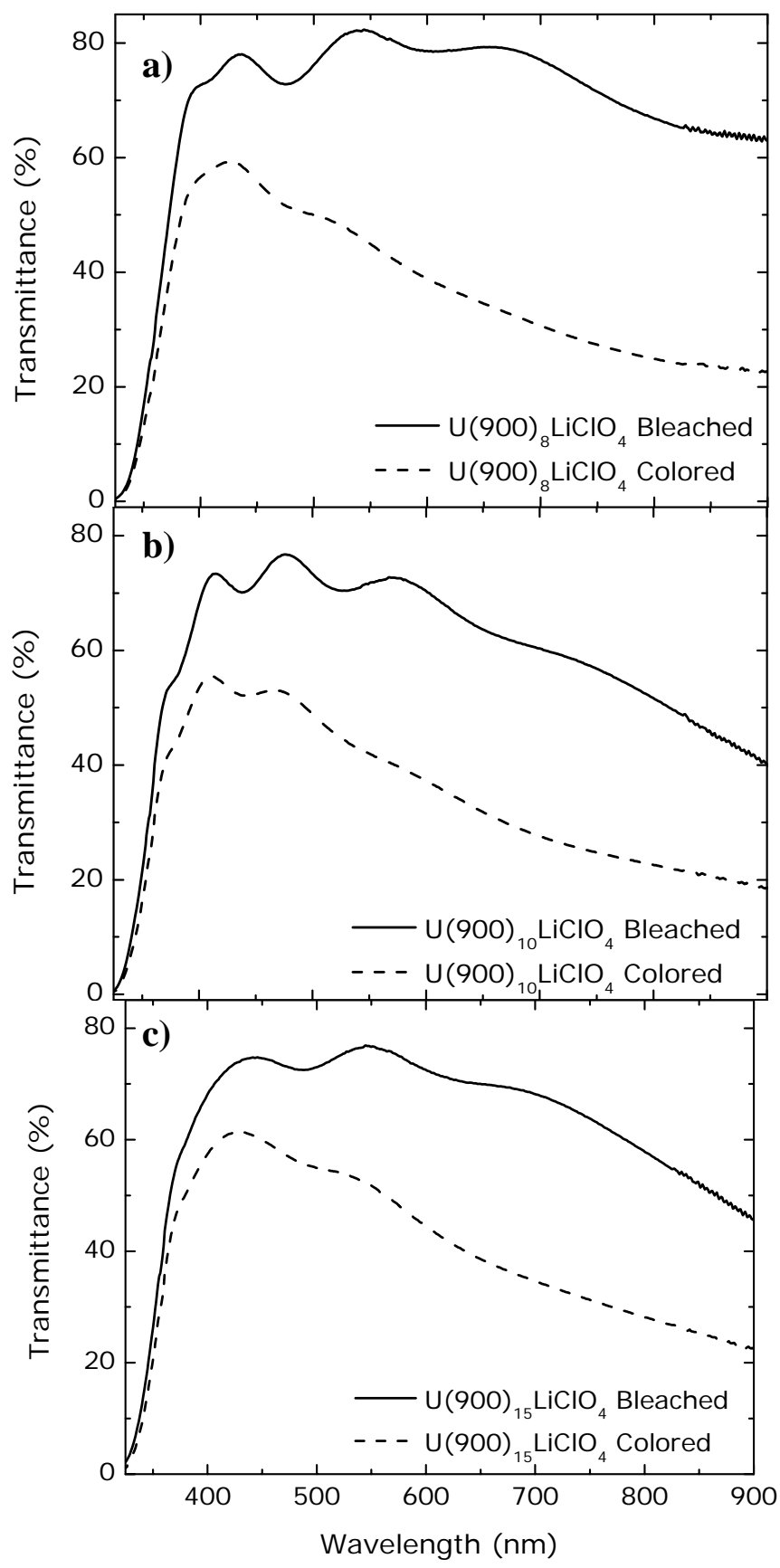

Fig. 10. Optical transmittance as a function of wavelength for the electrochromic device structure in bleached and colored state using (a) d-U(900) ${ }_{8} \mathrm{LiClO}_{4}$; (b) d-U(900) ${ }_{10} \mathrm{LiClO}_{4}$; (c) d-U(900) ${ }_{15} \mathrm{LiClO}_{4}$. 


\section{$\mathrm{U}(2000)_{20} \mathrm{LiClO}_{4}$}

\section{$\mathrm{U}(900)_{8} \mathrm{LiClO}_{4}$}

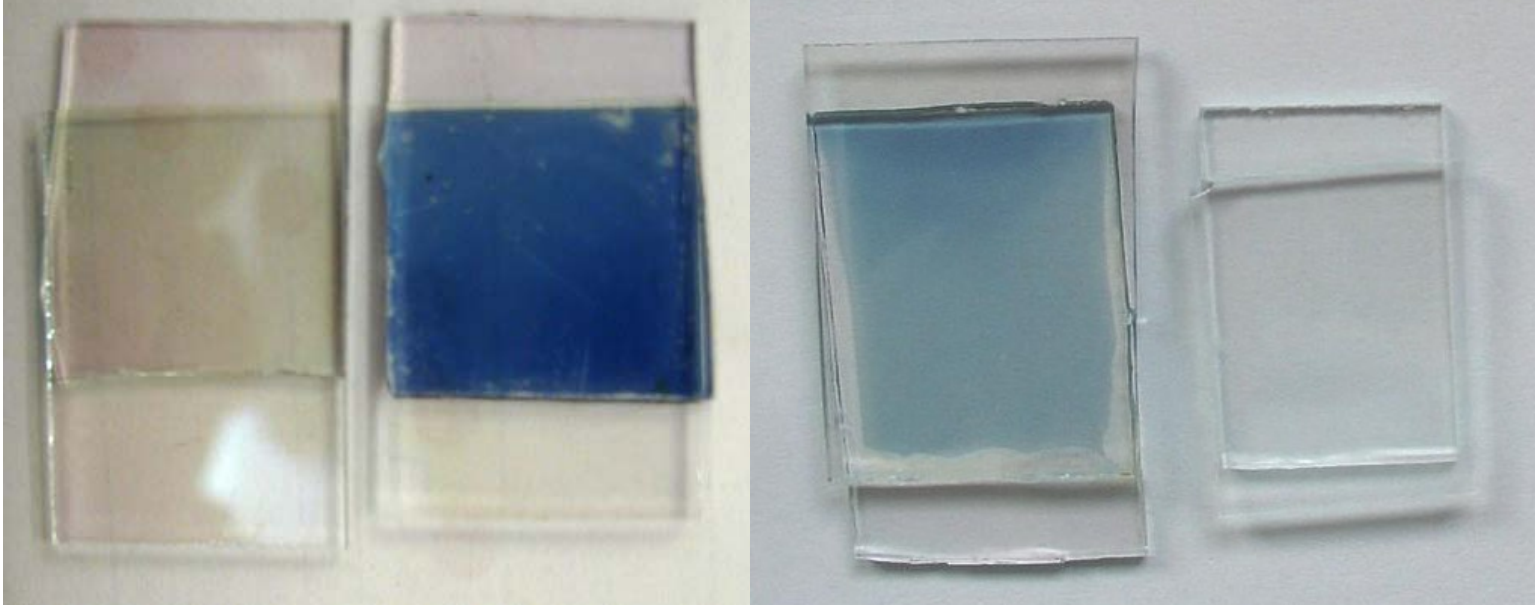

Fig. 11. Electrochromic device in bleached and colored states for compositions with highest ionic conductivity. 
Table 1

Average transmittance and optical density exhibited by electrochromic devices.

\begin{tabular}{cccc}
\hline \hline \multicolumn{1}{c}{ Sample } & Transmittance in bleached & Transmittance in colored & Optical \\
& state $(\%)$ & state $(\%)$ & density \\
\hline $\mathrm{U}(2000)_{20} \mathrm{LiClO}_{4}$ & 68.84 & 44.50 & 0.30 \\
\hline $\mathrm{U}(2000)_{30} \mathrm{LiClO}_{4}$ & 78.90 & 57.23 & 0.23 \\
\hline $\mathrm{U}(2000)_{40} \mathrm{LiClO}_{4}$ & 75.80 & 61.84 & 0.09 \\
\hline $\mathrm{U}(900)_{8} \mathrm{LiClO}_{4}$ & 68.40 & 44.45 & 0.30 \\
\hline $\mathrm{U}(900)_{10} \mathrm{LiClO}_{4}$ & 74.40 & 54.40 & 0.24 \\
\hline $\mathrm{U}(900)_{15} \mathrm{LiClO}_{4}$ & 75.90 & 58.05 & 0.17 \\
\hline \hline
\end{tabular}

